\title{
Threatened fishes of the world: Squalius aradensis (Coelho, Bogutskaya, Rodrigues \& Collares-Pereira, 1998) (Cyprinidae)
}

\author{
Carla Sousa-Santos • Joana I. Robalo • \\ Vítor C. Almada
}

Received: 25 March 2009 / Accepted: 13 October 2009

(C) Springer Science + Business Media B.V. 2009

Keywords Cyprinidae · Endemic · Iberian Peninsula

Common name: Escalo do Arade (Portuguese). Conservation status: Critically Endangered according to the Portuguese Red Data Book (Cabral et al. 2005). Identification: Small cyprinid with $131 \mathrm{~mm}$ of maximum standard length and 35-42 canaliculate scales on the lateral line, 7-8.5 scales above the lateral line, 2.5-3 scales below the lateral line, 8 dorsal and 7-8 anal fin rays. Pharyngeal teeth are two-rowed (2.5-5.2); vertebral formulae are $21+17$ or $21+16$; preopercular-mandibular cephalic sensory canal communicates with infraorbital canal; and fourth and fifth infraorbitals are large and completely fused (Coelho et al. 1998). Illustration: Marcos Oliveira. Distribution: This species is endemic to Portugal and occurs in the rivers Arade, Seixe, Algibre, Bordeira, Aljezur, Alvor and Quarteira. It was isolated from its sister species, Squalius torgalensis, around 5.13 MY ago due the uplift of the Caldeirão Mountains (Sousa-Santos et al. 2007). Abundance: It is estimated that the number of mature individuals is higher than 10.000 but strong seasonal

C. Sousa-Santos $(\bowtie) \cdot$ J. I. Robalo $\cdot$ V. C. Almada

Unidade de Investigação em Eco-Etologia, ISPA,

Rua Jardim do Tabaco, 34,

1149041 Lisboa, Portugal

e-mail: carla.santos@ispa.pt

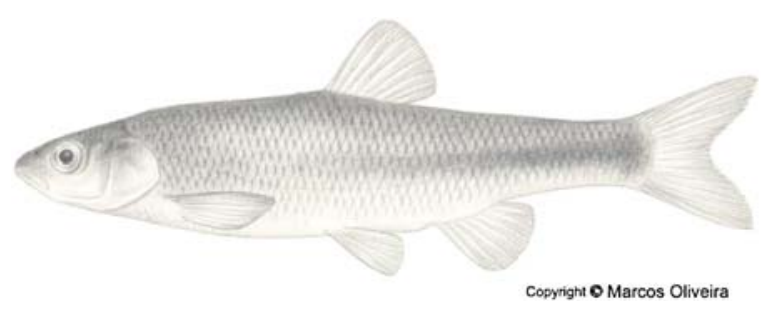

fluctuations may occur (Cabral et al. 2005). Habitat and ecology: Generalist species, inhabiting a broad range of habitats outside the reproductive season-in spring migrations towards higher velocity areas with coarse substrata seem to occur (Santos and Ferreira 2008). Reproduction: Breeding season is expected to be similar to that of $S$. torgalensis: March to June. Extensive hybridization with Squalius alburnoides occurs in the Quarteira River (Sousa-Santos et al. 2006). Threats: Dams, proliferation of introduced exotic species, water scarcity, habitat degradation and loss of water quality. Conservation: Some efforts are being conducted to the ex situ reproduction of this species. Conservation recommendations: Habitat restoration of some stretches followed by restocking with fish produced in ex-situ breeding programmes. Mesquita et al. (2005) suggested that conservation efforts should pay particular attention to isolated populations and smaller drainages, where low levels of genetic diversity were found (as a 
result of higher mortality rates during summer droughts and inbreeding).

\section{References}

Cabral MJ, Almeida J, Almeida PR et al (eds) (2005) Livro Vermelho dos Vertebrados de Portugal. Instituto de Conservação da Natureza, Lisboa

Coelho MM, Bogutskaya NG, Rodrigues JA, Collares-Pereira MJ (1998) Leuciscus torgalensis and Leuciscus aradensis, two new cyprinids for Portuguese freshwaters. J Fish Biol 52:937-950
Mesquita N, Hänfling B, Carvalho GR, Coelho MM (2005) Phylogeography of the cyprinid Squalius aradensis and implications for conservation of the endemic freshwater fauna of southern Portugal. Mol Ecol 14:1939-1954

Santos JM, Ferreira MT (2008) Microhabitat use by endangered Iberian cyprinids nase Iberochondrostoma almacai and chub Squalius aradensis. Aquat Sci 70:272-281

Sousa-Santos C, Collares-Pereira MJ, Almada VC (2006) Evidence of extensive mitochondrial introgression with nearly complete substitution of the typical Squalius pyrenaicus-like mtDNA of the Squalius alburnoides complex (Cyprinidae) in an independent Iberian drainage. J Fish Biol 68(Supplement B):292-301

Sousa-Santos C, Collares-Pereira MJ, Almada VC (2007) Reading the history of a hybrid fish complex from its molecular record. Mol Phylogenet Evol 45:981- 996 